\title{
New evidence of illicit cigarette consumption and government revenue loss in Indonesia
}

\author{
Rahmatina A. Kasri', Abdillah Ahsan' ${ }^{1}$, Nur Hadi Wiyono², Ardhini R. Jacinda', Dian Kusuma ${ }^{3}$
}

\begin{abstract}
INTRODUCTION Illicit cigarettes because of their affordability could increase smoking prevalence, especially among young people. They also cause a large revenue loss for the government. This study aims to estimate illicit cigarette consumption and government revenue loss in Indonesia, a country with a very high smoking prevalence, especially among males.

METHODS We estimated illicit cigarette trade in terms of volume and revenue loss. Illicit trade was estimated as the discrepancy between legal cigarette sales and domestic consumption recorded by national representative surveys. Data sources included Basic Health Research Survey, Global Adult Tobacco Survey, National Socioeconomic Survey, and data from Ministry of Finance.

RESULTS We found that illicit cigarette consumption fluctuated from 19 billion sticks in 2007 to 14 billion sticks in 2013, and sharply increased to 59 billion sticks in 2018. Relative to cigarette consumption, illicit cigarettes were the lowest at $5 \%$ in 2013 and highest at 19\% of consumption in 2018 (assuming 0\% underreporting). The estimated government revenue loss ranged from IDR 24.2 to 42.0 trillion (US\$ 1668 to 2897 million), which corresponds to $15.8 \%$ to $27.5 \%$ of cigarette excise revenue in 2018 .

CONCLUSIONS In Indonesia, illicit cigarette consumption was found to be high and increasing, which contributed to a large government revenue loss (almost onethird of tobacco excise tax revenue). To reduce illegal cigarette production and smuggling, the government should increase resources to enforce the regulation on the excise tax system including stronger penalties, especially related to illicit cigarette production.
\end{abstract}

AFFILIATION
1 Center for Islamic Business
and Economics, Faculty of
Economics and Business,
Universitas Indonesia, Depok,
Indonesia
2 Lembaga Demografi, Faculty
of Economics and Business,
Universitas Indonesia, Depok,
Indonesia
3 Centre for Health
Economics and Policy
Innovation, Imperial College
Business School, London,
United Kingdom
CORRESPONDENCE T0
Rahmatina A. Kasri. Center
for Islamic Business and
Economics, Faculty of
Economics and Business,
Kampus Baru Universitas
Indonesia, 1st Floor, Soenario
Kolopaking Building, Depok
16424, West Java, Indonesia.
E-mail: unirahma@gmail.com

KEYWORDS

illicit cigarette, cigarette consumption, revenue loss, Indonesia

Received: 29 January 2021 Revised: 23 June 2021

Accepted: 1 October 2021

\section{INTRODUCTION}

The World Health Organization (WHO) has estimated that the global illicit cigarette market accounts for $11.6 \%$ of the total market, resulting in US $\$ 40.5$ billion tax revenue loss per year ${ }^{1}$. Globally, the Asia and Pacific region have the highest illicit trade volume with 291 billion sticks in 2010, compared to 60 billion sticks in Eastern Europe, Latin America, Middle East and Africa ${ }^{1}$. Illicit cigarettes would increase cigarette consumption due to lower price. A study of 36 countries found that eliminating illicit cigarettes would reduce total cigarette consumption by $1.9 \%$. The decrease in the countries where illicit cigarettes are more than $15 \%$ of the market would average $4.1 \%{ }^{2}$.

The Protocol to Eliminate Illicit Trade in Tobacco Products asserted that all governments ratifying the Framework Convention on Tobacco Control (FCTC) are required to eliminate all forms of illicit trade in tobacco products, including smuggling, illicit manufacturing and counterfeiting ${ }^{3}$. Although Indonesia has not ratified FCTC, some measures have 
been taken to control illicit cigarette trade. Law No. $39 / 2007$ on excise tax stated that part of the $2 \%$ of the earmarked excise tax should be for combating illicit cigarettes. To eliminate illicit trade and production, Directorate General of Customs and Excise (DGCE) under the Ministry of Finance conducted a regular crackdown on illicit cigarette trade and production ${ }^{4}$.

Illicit cigarette trade includes smuggled cigarettes and illegal domestic production. It has been suggested by the Indonesian Ministry of Health that smuggling is around $5 \%$ of the domestic sales ${ }^{5}$. This relatively low estimate reflects the preference for kreteks above white cigarettes, which predominate in the illicit cigarette trade, and makes smuggling into Indonesia unprofitable. Ninety percent of smokers prefer smoking kretek, a tobacco and clove cigarette produced almost exclusively in Indonesia, often illegally ${ }^{6}$.

Illicit cigarette trade undermines tobacco control policies by lowering prices and encouraging consumption particularly by young and poor people in Indonesia. Data from Basic Health Research, a nationally representative survey, showed the prevalence of smoking among adults remained high from $34.2 \%$ to $33.8 \%$ between 2007 and 2018 . Smoking prevalence among youth (aged 10-18 years) increased from $7.2 \%$ to $9.1 \%$ between 2013 and 2018 . Moreover, illicit cigarettes encourage the smokers who are poor to continue smoking even when the government raises tobacco taxes and increases the price of legal cigarettes ${ }^{7}$. Smoking prevalence of the poorest quintile households was higher $(32.6 \%)$ than the richest $(28.9 \%)^{6}$. One impact is undernutrition among children. A study showed that Indonesian children with smoking parents were $5.5 \%$ shorter than those whose parents did not smoke ${ }^{8}$.

Indonesia's complicated tobacco excise tax system (differential tax rates) creates incentives for tobacco companies to reduce their production levels to fall within lower tax brackets 9 . Tobacco tax is determined by the type of cigarette, the scale and method of production, and the retail price range. The average excise tax in 2019 was $44.7 \%$, while the maximum allowable cigarette excise tax according to excise law is $57 \%$. However, the cigarette tax burden as percentage of retail price that is excise tax plus Value Added Tax (VAT) and local cigarette tax is $58.3 \%{ }^{10}$. Other ASEAN countries, the cigarette tax burden is $70.0 \%$ in
Thailand, 62.0\% in Brunei, 67.5\% in Singapore, 61.7\% in Philippines, and $53-58 \%$ in Malaysia ${ }^{11}$. Studies in Indonesia have shown that increasing tobacco excise tax is a win-win situation ${ }^{9}$. A $10 \%$ increase in tobacco excise tax would result in a $0.9-3.0 \%$ reduction in consumption and a $7-9 \%$ increase in tobacco excise revenue?

There are previous estimates on the magnitude of illicit cigarettes in Indonesia, but with several limitations. Researchers at Universitas Gadjah Mada purchased cigarette packs and found that the proportion of illicit cigarette packs increased from $6.1 \%$ in 2010 to $12.1 \%$ in 2016 , but decreased to $7.0 \%$ in $2018^{12}$. Another study by Oxford Economics used empty-pack survey methodology and found that domestic illicit cigarettes increased from 26.2 billion sticks ( $8.5 \%$ of total consumption) in 2012 to 30.9 billion sticks ( $9.6 \%$ of total consumption) in $2017^{13}$. However, the pack and empty-pack surveys used in those two studies were likely to have underestimated illicit consumption ${ }^{13,14}$. Researchers from The Prakarsa interviewed 1440 adult smokers in six provinces and found that $20 \%$ of respondents stated that they had smoked illicit cigarettes at least once. They also collected 1201 cigarette packs, of which $2 \%$ were found to be illicit, through the validity of excise tapes and health warning image ${ }^{14}$. However, the sample of smokers used in the Prakarsa study was relatively small and not nationally representative. Researchers from Universitas Indonesia (Ahsan et al. ${ }^{15}$ ) estimated that illegal cigarettes were $17 \%$ and $9 \%$ of the total consumption in 2004 and 2013 , respectively. However, the study did not take into account value added tax and local cigarette tax - the government implemented a local cigarette tax for all cigarettes to be sold in Indonesia to be $10 \%$ of cigarette excise tax in 2014. Thus, our study aimed to assess the magnitude of illicit cigarette consumption and associated revenue loss by using nationally representative cigarette consumption and production data, which included VAT and local cigarette tax.

\section{METHODS}

Merriman ${ }^{16}$ identified five broad approaches to estimating tobacco smuggling: 1) interviewing experts, 2) observing smokers and their habits, 3) comparing legal tobacco sales with consumption estimated from surveys, 4) monitoring tobacco trade, 
and 5) using econometric analyses. In this study, we used the third approach by comparing tax paid in sales data with survey consumption data. We then estimate government revenue loss due to illegal domestic cigarette production. A simple formula in Microsoft Excel was used to process and analyze the data. The method estimates the magnitude of illicit cigarettes as consumption from surveys minus legal sales ${ }^{16}$, as presented below:

- Legal sales/tax-paid sales: $\mathrm{S}=\mathrm{P}$ - (M - X);

- Illicit consumption: $\mathrm{I}=\mathrm{C}-\mathrm{S}$;

- Illicit cigarette trade is taking place as a net smuggling in and/or illegal domestic cigarette production if: $(\mathrm{C}-\mathrm{P})>(\mathrm{M}-\mathrm{X})$;

- Illicit cigarette trade is taking place as a net smuggling out and/or underreporting of consumption if: $(\mathrm{C}-\mathrm{P})<(\mathrm{M}-\mathrm{X})$;

where $\mathrm{P}$ is domestic legal production, $\mathrm{M}$ is import, $\mathrm{X}$ is export, and $\mathrm{C}$ is consumption (survey-based).

\section{Estimating government revenue loss}

Government revenue loss from illegal domestic cigarette is calculated using the formula:

$\mathrm{L}=\mathrm{ID} \times(\mathrm{E}+\mathrm{VAT}+\mathrm{LT})$

where $\mathrm{L}$ is government revenue loss due to illegal domestic cigarettes, ID is quantity of illegal domestic cigarette production, $\mathrm{E}$ is cigarette excise tax, VAT is value added tax, and LT is local cigarette tax. Total government revenue loss is lost revenue from smuggled cigarettes plus lost revenue from illegal domestic cigarettes.

The value of sales of illegal domestically produced cigarettes uses market share of three types of manufactured cigarettes namely machine-made kreteks cigarette, machine-made white cigarettes, and handmade cigarettes. Market share for type of cigarette is slightly different between 2016 and 2018. We limited calculations to these years to estimate the revenue loss. Market of machine made kretek cigarettes, machine made white cigarettes, and handmade cigarettes was $74 \%, 6 \%$, and $21 \%$ of domestic consumption, respectively, in 2016 . The market share was $76 \%, 5 \%$, and $20 \%$ in 2018 , respectively. These market shares were then used to calculate the numbers of illicit cigarettes. Each type of cigarette has different excise tariff, so we used the lowest and the highest tariff, instead of the excise average. In turn, the number of illicit cigarettes was multiplied by the highest and lowest tiers tariff for each cigarette type, which provided an upper and lower bound for the estimates of revenue loss. Since there are ten types of excise tariffs, we did not calculate each type of cigarette revenue loss, instead we calculated the range of revenue loss (the lowest and the highest) from three types of cigarettes: machine made kretek cigarettes, machine made white cigarettes, and handmade cigarettes.

The government imposed VAT for cigarettes sold in the country at $8.7 \%$ in 2016 and $9.1 \%$ of retail price in 2018. We calculated the VAT for each type of cigarette. Under Law 28/2009 on Local Tax and Local Retribution, the government also imposes local cigarette tax as much as $10 \%$ of excise revenue that will be transferred to the provincial government, since 2014. The local cigarette tariff is $10 \%$ of cigarette excise tariff.

\section{Data sources}

There are three types of data use in our analysis within the 2007-2018 period. First, data on cigarette consumption (i.e. smoking prevalence and average daily cigarette use) were obtained from the published reports of Ministry of Health (e.g. Basic Health Research Surveys 2007, 2010, 2013, 2018 and Global Adult Tobacco Survey 2011) and Statistics Indonesia (e.g. National Socio-Economic Survey 2016). Second, data on cigarette production (i.e. excise stamps orders by cigarette industry) were obtained from Ministry of Finance (Fiscal Policy Office). We assumed that all cigarettes were absorbed by the market in the production year. Third, data on population estimates were based on population projections produced by Statistics Indonesia.

\section{RESULTS}

\section{Illicit cigarette consumption}

Table 1 shows smoking prevalence, intensity and cigarette consumption in Indonesia 2007-2018. With the population aged $\geq 15$ years reaching 195 million in 2018, cigarette consumption was high at 308 billion sticks in Indonesia. This was an increase from 212 billion sticks in 2007 or an increase of $45 \%$. Population aged $\geq 15$ years steadily increased over time. Smoking prevalence slightly decreased from $34.2 \%$ to $33.8 \%$ in 2018 , although it increased in 2011. Smoking intensity by smokers increased from 
10.2 sticks/day in 2017 to 12.8 sticks/day in 2018 .

Table 2 shows cigarette production, sales and illicit consumption in Indonesia during 2007-2018. Cigarette production increased from 242 billion sticks in 2007 to 346 billion sticks in 2013 but decreased to 332 billion sticks in 2018. Net exports increased steadily from 48.1 to 84.2 billion sticks in 2007 and 2018, respectively. Tax-paid sales (i.e. legal sales) also increased gradually from 193.4 billion sticks in 2007 to 278.9 billion sticks in 2013 but decreased to 248.2 billion sticks in 2018. Cigarette consumption increased steadily during the period from 212.5 to 307.6 billion sticks between 2007 and 2018 , respectively. Cigarette consumption exceeded legal sales during 2007-2018, except in 2010. Thus, under for $0 \%$ underreporting level, illicit cigarette consumption fluctuated from 19.1 billion sticks in 2007 to 13.8 billion sticks in 2013 and sharply increased to 59.4 billion sticks in 2018 . The proportion of illicit cigarettes relative to consumption was lowest at $5 \%$ in 2013 and highest at $19 \%$ in 2018 . When underreporting of smokers was taken into account, the magnitude of illicit cigarettes varied. Using $5 \%$ underreporting, illicit consumption was highest at 75 billion sticks or $24 \%$ of consumption. However, using $15 \%$ underreporting, illicit cigarette consumption was 106 billion sticks or $34 \%$ of consumption. We argue that $0 \%$ underreporting is likely because smoking is socially acceptable in Indonesia. Moreover, results also show negative values of illicit cigarettes in 2010, which means legal sales exceeded consumption mainly due to a sharp increase in the production in 2010 (compared to 2007).

\section{Government revenue loss}

Table 3 shows government revenue loss due to illicit cigarettes (assuming 0\% underreporting) in 2016 and 2018. The revenue loss from excise cigarette tax (including VAT and local tax) is presented as a range of lower and upper bounds of excise tax losses given the assessed rates, proportion of cigarette types consumed by smokers, and the proportion of cigarettes that are smuggled into Indonesia. Results show two ranges for 2016 and 2018 using two scenarios: a) no illicit cigarettes from abroad (no smuggling), and b) $10 \%$ of illicit trade from abroad (smuggling). The upper bound was the sum of the numbers of cigarettes in each type multiplied by the highest excise tariff for that cigarette type. The lower bound used the lowest excise tariff assessed for each cigarette type.

First, assuming no smuggling, revenue loss ranged

Table 1. Smoking prevalence, intensity and cigarette consumption in Indonesia, 2007-2018

\begin{tabular}{|c|c|c|c|c|}
\hline Year & $\begin{array}{c}\text { Smoking } \\
\text { prevalence } \\
(\%)\end{array}$ & $\begin{array}{l}\text { Population } \\
\text { (aged } \geq 15 \\
\text { years) } \\
\text { (million) }\end{array}$ & $\begin{array}{l}\text { Smoking } \\
\text { intensity } \\
\text { (sticks/ } \\
\text { day) }\end{array}$ & $\begin{array}{l}\text { Estimated } \\
\text { consumption } \\
\text { (billion sticks) }\end{array}$ \\
\hline & $A$ & B & C & $\mathrm{A} \times \mathrm{B} \times \mathrm{C} \times 365$ days \\
\hline 2007 & 34.2 & 166.9 & 10.2 & 212.51 \\
\hline 2010 & 34.3 & 170.4 & 10.1 & 215.47 \\
\hline 2011 & 34.8 & 173.5 & 12.8 & 282.09 \\
\hline 2013 & 36.3 & 179.6 & 12.3 & 292.69 \\
\hline 2016 & 32.8 & 189.1 & 12.6 & 285.25 \\
\hline 2018 & 33.8 & 194.8 & 12.8 & 307.62 \\
\hline
\end{tabular}

Basic Health Research Survey 2007, 2010, 2013 and 2018; National Socioeconomic Survey 2016; and Global Adult Tobacco Survey 2011.

Table 2. Production and sales (billion sticks) and illicit consumption of cigarettes, 2007-2018

\begin{tabular}{|c|c|c|c|c|c|c|c|c|c|c|c|c|}
\hline \multirow[t]{2}{*}{ Year } & \multirow[t]{2}{*}{ Production } & \multirow[t]{2}{*}{ Net exports } & \multirow{2}{*}{$\begin{array}{c}\text { Tax-paid } \\
\text { sales }\end{array}$} & \multirow[t]{2}{*}{ Consumption } & \multicolumn{8}{|c|}{ Illicit cigarette consumption underreporting level* } \\
\hline & & & & & $0 \%$ & $\begin{array}{l}\% \text { of } \\
\text { Cons. }\end{array}$ & $5 \%$ & $\begin{array}{l}\% \text { of } \\
\text { Cons. }\end{array}$ & $10 \%$ & $\begin{array}{l}\% \text { of } \\
\text { Cons. }\end{array}$ & $15 \%$ & $\begin{array}{l}\% \text { of } \\
\text { Cons }\end{array}$ \\
\hline 2007 & 241.50 & 48.08 & 193.42 & 212.51 & 19.09 & 9.0 & 29.71 & 14.0 & 40.34 & 19.0 & 50.96 & 24.0 \\
\hline 2010 & 289.10 & 54.90 & 234.20 & 215.47 & -18.74 & -8.7 & -7.96 & -3.7 & 2.81 & 1.3 & 13.58 & 6.3 \\
\hline 2011 & 317.81 & 55.83 & 261.98 & 282.09 & 20.11 & 7.1 & 34.21 & 12.1 & 48.31 & 17.1 & 62.42 & 22.1 \\
\hline 2013 & 345.89 & 66.97 & 278.92 & 292.69 & 13.77 & 4.7 & 28.41 & 9.7 & 43.04 & 14.7 & 57.68 & 19.7 \\
\hline 2016 & 341.73 & 76.73 & 265.00 & 285.25 & 20.25 & 7.1 & 34.51 & 12.1 & 48.77 & 17.1 & 63.04 & 22.1 \\
\hline 2018 & 332.40 & 84.20 & 248.20 & 307.62 & 59.42 & 19.3 & 74.80 & 24.3 & 90.18 & 29.3 & 105.56 & 34.3 \\
\hline
\end{tabular}

Calculations based on data from Directorate General of Excise and Customs, Ministry of Finance for cigarette productions, Central Board of Statistics for Net Exports. Tax-paid sales represent production minus net exports. Negative values indicate the absence of illicit cigarette consumption. ${ }^{*}$ A sensitivity analysis was performed assuming levels of underreporting of $0,5,10$ and $15 \%$ of actual cigarettes smoked. 
Table 3. Government revenue loss due to illicit cigarettes (assuming no underreporting), Indonesia, 2016 and 2018

\begin{tabular}{|c|c|c|c|c|c|}
\hline \multirow{3}{*}{$\begin{array}{l}\text { Category } \\
\text { Origin of illicit consumption (\%) }\end{array}$} & \multirow{2}{*}{$\begin{array}{l}\text { Subcategory } \\
\text { Illicitly produced }\end{array}$} & \multicolumn{2}{|c|}{2016} & \multicolumn{2}{|c|}{2018} \\
\hline & & 95 & 100 & 95 & 100 \\
\hline & Smuggled & 5 & 0 & 5 & 0 \\
\hline \multirow[t]{2}{*}{ Illicit cigarettes (billion sticks) } & Illicitly produced & 19.2 & 20.2 & 56.4 & 59.4 \\
\hline & Smuggled & 1.0 & 0 & 3.0 & 0 \\
\hline \multirow{3}{*}{$\begin{array}{l}\text { Proportion of domestic consumption } \\
(\%)\end{array}$} & Machine made kretek cigarettes & 74 & 74 & 76 & 76 \\
\hline & Machine made white cigarettes & 6 & 6 & 4 & 4 \\
\hline & Handmade kretek cigarettes & 21 & 21 & 20 & 20 \\
\hline \multirow[t]{3}{*}{ Lowest tax tiers (IDR) } & Machine made kretek cigarettes & 300 & 300 & 370 & 370 \\
\hline & Machine made white cigarettes & 255 & 255 & 355 & 355 \\
\hline & Handmade kretek cigarettes & 80 & 80 & 100 & 100 \\
\hline \multirow[t]{3}{*}{ Highest tax tiers (IDR) } & Machine made kretek cigarettes & 480 & 480 & 590 & 590 \\
\hline & Machine made white cigarettes & 495 & 495 & 625 & 625 \\
\hline & Handmade kretek cigarettes & 320 & 320 & 365 & 365 \\
\hline $\begin{array}{l}\text { Value added tax (\%) (VAT rate } \times \\
\text { retail price) }\end{array}$ & & 8.7 & 8.7 & 9.1 & 9.1 \\
\hline \multirow[t]{3}{*}{ Local cigarette tax, lowest tiers (IDR) } & Machine made kretek cigarettes & 30 & 30 & 37 & 37 \\
\hline & Machine made white cigarettes & 25.5 & 25.5 & 35.5 & 35.5 \\
\hline & Handmade kretek cigarettes & 8 & 8 & 10 & 10 \\
\hline \multirow{3}{*}{$\begin{array}{l}\text { Local cigarette tax, highest tiers } \\
\text { (IDR) }\end{array}$} & Machine made kretek cigarettes & 48 & 48 & 59 & 59 \\
\hline & Machine made white cigarettes & 49.5 & 49.5 & 62.5 & 62.5 \\
\hline & Handmade kretek cigarettes & 32 & 32 & 37 & 37 \\
\hline \multirow{2}{*}{$\begin{array}{l}\text { Estimated revenue loss range } \\
\text { (trillion IDR) }\end{array}$} & Estimate, lowest tier & 6.7 & 6.7 & 24.8 & 24.2 \\
\hline & Estimate, highest tier & 11.9 & 11.8 & 41.8 & 42.0 \\
\hline \multirow{2}{*}{$\begin{array}{l}\text { Estimated revenue loss range } \\
\text { (million US\$) }\end{array}$} & Estimate, lowest tier & 499.0 & 486.2 & 1712.8 & 1668.2 \\
\hline & Estimate, highest tier & 865.3 & 871.8 & 2880.2 & 2897.0 \\
\hline \multirow{3}{*}{$\begin{array}{l}\text { Estimated revenue loss range as } \\
\text { share of tobacco excise taxes }\end{array}$} & Total tobacco excise revenue (trillion IDR) & 137.9 & 137.9 & 152.9 & 152.9 \\
\hline & Share of tobacco excise revenue, lowest tier (\%) & 4.9 & 4.8 & 16.2 & 15.8 \\
\hline & Share of tobacco excise revenue, highest tier (\%) & 8.5 & 8.5 & 27.3 & 27.5 \\
\hline
\end{tabular}

Official exchange rates used for Indonesian Rupiah: IDR 13500 per US\$1.0 in 2016 and 14500 in 2018.

from IDR 6.6 trillion to 11.8 trillion, or between $4.8 \%$ and $8.5 \%$ of cigarette excise tax revenue in 2016. Revenue loss ranged from IDR 24.2 to 42.0 trillion, or $15.8 \%$ to $27.5 \%$ of cigarette excise tax revenue in 2018. Higher revenue loss in 2018 was due to the decrease in cigarette production from 342 to 332 billion sticks in 2016 and 2018, respectively. Meanwhile, cigarette consumption increased from 285 to 308 billion sticks in 2016 and 2018 , respectively, as the population grew. Second, assuming $5 \%$ cigarette smuggling, the revenue loss ranged from IDR 6.7 trillion to 11.9 trillion or $4.9 \%$ and $8.5 \%$ in 2016 . The revenue loss was higher in 2018 , ranging from IDR 24.8 to 41.8 trillion or $16.2 \%$ and $27.3 \%$ of revenue from cigarette excise revenue in 2018 .

\section{DISCUSSION}

We found that illicit cigarette consumption fluctuated from 19 billion sticks in 2007 to 14 billion sticks in 2013, and sharply increased to 59 billion sticks in 2018. Relative to cigarette consumption, illicit cigarettes were the lowest at 5\% in 2013 and highest at $19 \%$ of consumption in 2018 (assuming 0\% underreporting). This finding aligns with the study of Ahsan et al. ${ }^{15}$ that found that the illicit cigarette consumption made up $8 \%$ in 2013 . Our results also align with the study from Prakarsa ${ }^{14}$ which found 
that $20 \%$ of smoking respondents stated that they had smoked illicit cigarettes at least once. However, our estimate is higher compare to the studies by Universitas Gadjah Mada and Oxford Economics, possibly due to the potential underestimate of the pack and empty-pack survey methodology $y^{12,13}$.

For 2010, our results show negative values of illicit cigarettes, which means legal sales exceeded consumption, mainly due to a sharp increase in the production (compared to 2007). However, we are not aware of any specific factors that may have contributed to the production increase. The negative values may also be due to an underestimate in the cigarette consumption (e.g. due to different data sources). For instance, smoking intensity was 10.2 sticks/day in 2007 and 10.1 sticks/day in 2010, but then increased sharply to 12.8 sticks/day in 2011. In our analysis, we used Basic Health Survey data for 2007 and 2010, and Global Adult Tobacco Survey data for 2011.

Our result show that the estimated government revenue loss ranged from IDR 24.2 to 42.0 trillion (US\$ 1668 to 2897 million), which corresponds to $15.8-27.5 \%$ of cigarette excise revenue in 2018 . The study of Ahsan et al. ${ }^{15}$ found excise tax losses due to illicit cigarette consumption of IDR 9.3 trillion or $13 \%$ of tobacco excise tax revenue in 2013 . While Oxford Economics found excise tax revenue loss of IDR 13.3 trillion in 2017 or $6.5 \%$ of potential total tobacco excise tax revenue.

There are many factors that may contribute to the increase in illicit cigarettes. Corruption and the presence of organized crime might be a part of it $^{17}$. To facilitate smuggling at different stages of the supply chain of illicit cigarettes, smugglers either bribe customs officials to allow movements of illicit cigarettes across borders or bribe law enforcement officials to allow illegal manufacturing activities ${ }^{18}$. Arguments from cigarette companies/industry include that the increase in illicit cigarette consumption was caused by high excise tariffs that lead to decreasing production and uncontrolled consumption and loss of tax revenues ${ }^{14}$. They also argue that the standardizing of cigarette packaging can be another factor towards increasing illicit cigarettes.

However, the $10.5 \%$ and $10.0 \%$ increases in tobacco excise tax in 2017 and 2018, respectively, did not significantly affect cigarette consumption in 2018 .
Cigarette consumption still increased from 285.3 to 307.6 billion sticks between 2016 and 2018. On the other hand, the production decreased from 341.7 to 332.4 billion sticks between 2016 and 2018. Also, there was a large volume of net export of 84.2 billion sticks in 2018. Cigarette consumption was much greater than the amount of cigarette tax paid sales in 2018. The difference was 59.4 billion sticks, which indicated that illicit cigarettes were from illegal domestic production and smuggling in.

When cigarette sales were compared to cigarette consumption, there was a huge discrepancy which indicates that many cigarettes might not be declared by cigarette manufactures and excise tax was thus not paid. Since the government does not implement a track and trace measures, it is difficult to track cigarettes that are produced by manufactures. A good trackand-trace system would help to find underdeclared domestic cigarette production or production declared for export but then sold domestically ${ }^{7}$. Tracking and tracing systems for the legal supply chain, and visible and invisible security features (e.g. holograms) that should facilitate law enforcement help authorities and consumers detect illicit tobacco products. To some extent, the cigarette excise stamp in Indonesia contains a hologram that is difficult to forge ${ }^{2}$.

There are several relevant policies related to law enforcement on violations with regard to illegal cigarette production and sale. Law enforcement against violators is regulated in Law No. 39/2007 on excise $\operatorname{tax}^{19}$. The application of penalties for violators is the administrative sanctions and imprisonment sanctions that are regulated in Article 54 of Law No. 39/2007 concerning excise in conjunction with Article 65 paragraph (1) of the Criminal Code which states: 'Anyone who deliberately offers, hands out, oversells, or provides for sale excisable goods which are not packaged for retail sale or which are not affixed with excise stamps or are not affixed with other marks of payment of excise as referred to in Article 29 paragraph (1), is liable to a minimum of 1 (one) year and a maximum of 5 (five) years imprisonment and/ or a fine of at least 2 (two) times the value of excise and a maximum of 10 (ten) times the value of excise that industries or producers should pay'.

Furthermore, some policy strategies from other countries can be adapted to minimalize and tackle this huge illicit cigarette consumption. In Europe, 
the governments made an agreement with some of the Transnational Tobacco Companies (TTC), which dominate the market, to prevent them from cigarette smuggling and illegal selling of cigarettes ${ }^{20}$. It can be a solution since evidence that industries involved directly and indirectly in the cigarette smuggling appeared in a court judgment, internal documents, and admissions of TTCs ${ }^{20}$. British American Tobacco (BAT) documents showed that corporate objectives drive tobacco smuggling, and it can be an important factor affecting cigarette smuggling and illicit cigarette consumption. The agreement has forced the companies to make an annual payment and additional payment if they fail to control their supply chain, making their products slip into the illegal market ${ }^{20}$.

Policies need to be implemented in the light of the significant tax revenue to be gained if smuggling and illegal production is minimized, and because it would improve the health and life expectancy of the population. Other ways to reduce illicit trade include limiting duty-free sales, imposing regulation to use special labels and packaging, and licensing of manufacturers, importers, exporters, wholesalers, transporters, warehouses and retailers producing and distributing tobacco products. Cooperation between neighboring countries within the region is also important as smuggling occurs largely across their borders ${ }^{18}$. Other responsive laws and prevention policies should be implemented as well to minimize the volume of illicit cigarette consumption by adapting some of the policies and strategies of countries that have succeeded in reducing the illicit cigarette consumption and smuggling volume, to provide the government with the rationale to improve law enforcement. At community level, by using a $2 \%$ excise revenue sharing, the local government could empower the local community (village head, community leader, and community-based organizations) by conducting discussions and workshops on illegal activities of cigarette production and distribution in their areas. The awareness of the community is important to curb illicit cigarette production and distribution.

\section{Strengths and limitations}

Unlike previous estimates, our study used nationally representative data on cigarette consumption and cigarette production data, which included information on VAT and local cigarette tax. However, our study has at least two limitations. First, our analysis used different sources for cigarette consumption, which may contribute to inconsistency in the results over time. Second, we only used published reports on cigarette consumption, which did not allow us to provide confidence intervals in our estimates.

\section{CONCLUSIONS}

In Indonesia, illicit cigarette consumption is high and increasing, which contributes to a large government revenue loss (almost one-third of tobacco excise tax revenue). To reduce illegal cigarette production and smuggling, the government should increase resources to enforce the regulation on the excise system including stronger penalties, especially related to illicit cigarette production.

\section{REFERENCES}

1. World Health Organization. Illicit Trade in Tobacco: A Summary of The Evidence and Country Response. Accessed October 22, 2021. https://web.archive.org/ web/20210809090817/https://www.who.int/tobacco/ economics/illicittrade.pdf

2. Goodchild M, Paul J, Iglesias R, Bouw A, Perucic AM. Potential impact of eliminating illicit trade in cigarettes: a demand-side perspective. Tob Control. 2020;1-8. doi:10.1136/tobaccocontrol-2020-055980

3. WHO Framework Convention on Tobacco Control. Protocol to Eliminate Illicit Trade in Tobacco Products. World Health Organization; 2013. Accessed January 29, 2021. http://apps.who.int/iris/ bitstream/handle/10665/80873/9789241505246_ eng.pdf;jsessionid=42 7 DC57F34FDD8BA357 B 2DF65C722BD4? sequence $=1$

4. Ahsan A. Indonesia: Tackling Illicit Cigarette. In: Dutta S, ed. Confronting Illicit Tobacco Trade: A Global Review of Country Experiences. The World Bank; 2019. Accessed January 29, 2021. https://documents1. worldbank.org/curated/en/677451548260528135/ pdf/133959-REPL-PUBLIC-6-2-2019-19-59-24WBGTobaccoIllicitTradeFINALvweb.pdf

5. Ministry of Health of the Republic of Indonesia. The Tobacco Source Book: Data to support a National Tobacco Control Strategy. Ministry of Health of the Republic of Indonesia; 2004. Accessed January 29, 2021. https:// www.tobaccofreekids.org/assets/global/pdfs/reports_ articles/tobaccosourcebook_indonesia.pdf

6. The Indonesian Public Health Association. Indonesia Tobacco Facts, 2020: Empirical Data for Tobacco Control. In Indonesian. 2020.

7. Dutta S. Confronting Illicit Tobacco: Global Review of Country Experiences. World Bank Group; 2019:xixxiii. Accessed January 29, 2021. https://documents 1 . 
worldbank.org/curated/en/677451548260528135/ pdf/133959-REPL-PUBLIC-6-2-2019-19-59-24WBGTobaccoIllicitTradeFINALvweb.pdf

8. Dartanto T, Nurhasana R, Satrya A, Thabrany H. Parents' Smoking Behavior and its Impact on Stunting and the Poverty Trap. Report in Indonesian. Universitas Indonesia; 2018.

9. Barber S, Adioetomo SM, Ahsan A, Setyonaluri D. Tobacco Economics in Indonesia. International Union Against Tuberculosis and Lung Disease; 2008. Accessed October 22, 2021. https://www.tobaccofreekids.org/assets/ global/pdfs/en/Indonesia_tobacco_taxes_report_en.pdf

10. Ministry of Finance, Fiscal Policy Office. Workshop material on Financing Public Health Program: Taxation Policy on Tobacco Product. 2019.

11. Lian TY, Dorotheo U. The Tobacco Control Atlas: ASEAN Region. Southeast Asia Tobacco Control Alliance; 2018. Accessed January 29, 2020. https://seatca.org/dmdocuments/ SEATCA\%20Tobacco\%20Control\%20Atlas\%20ASEAN\%20 Region\%204th\%20Ed\%20Sept\%202018.pdf

12. Center for Economics and Public Policies Studies, Universitas Gadjah Mada. Survey on Excise of Illegal cigarettes, in Annual Performance Report, Directorate General Custom and Excise. In Indonesian. Ministry of Finance; 2017.

13. Oxford Economics. Asia Illicit Tobacco Indicator 2017: Indonesia. Accessed April 19, 2021. https:// illicittobacco.oxfordeconomics.com/media/OXFO5877_ Indonesia_2018_Report.pdf

14. Kartika W, Thaariq RM, Ningrum DW, Ramdlaningrum H. Cigarette Industry Claims on Illicit Cigarette Sale Are Baseless. In Indonesian. The Prakarsa Policy Brief; 2019.

15. Ahsan A, Wiyono NH, Setyonaluri D, Denniston R, So AD. Illicit cigarette consumption and government revenue loss in Indonesia. Global Health. 2014;10. doi:10.1186/s12992-014-0075-7

16. Merriman D. Tool 7: Understand, Measure, and Combat Tobacco Smuggling. World Bank Economics of Tobacco Toolkit. Accessed January 29, 2020. https://openknowledge.worldbank.org/bitstream/ handle/10986/16267/805800NWP070Sm0Box037 9807B00PUBLIC0.pdf? sequence $=1 \&$ isAllowed $=y$

17. Brown J, Welding K, Cohen JE, et al. An analysis of purchase price of legal and illicit cigarettes in urban retail environments in 14 low- and middle-income countries. Addiction. 2017;112(10):1854-1860. doi:10.1111/add.13881

18. United Nations Office on Drugs and Crime. Transnational Organized Crime in Southeast Asia: Evolution, Growth and Impact. United Nations Office on Drugs and Crime; 2019. Accessed April 4, 2020. https://www.unodc.org/ documents/southeastasiaandpacific/Publications/2019/ SEA_TOCTA_2019_web.pdf

19. Law of the Republic of Indonesia Number 39 Year 2007 on Amendments to Law No. 11 Year 1995 on Excise. Accessed
January 29, 2020. https://www.tobaccocontrollaws.org/ files/live/Indonesia/Indonesia\%20-\%20Law\%20No.\%20 39_2007\%20\%28Tax\%29.pdf

20. Joossens, L, Gilmore AB, Stoklosa M, Ross H. Assessment of the European Union's illicit trade agreements with the four major Transnational Tobacco Companies. Tob Control. 2016;25:254-260. doi:10.1136/tobaccocontrol-2014-052218

\section{ACKNOWLEDGEMENTS}

We express our gratitude to Universitas Indonesia for providing a grant to conduct the study.

\section{CONFLICTS OF INTEREST}

The authors have each completed and submitted an ICMJE form for disclosure of potential conflicts of interest. The authors declare that they have no competing interests, financial or otherwise, related to the current work. All the authors report that since the initial planning of the work and in the past 36 months, this work was supported by Universitas Indonesia Research Grant (Hibah UI) RAK.

\section{FUNDING}

This work was supported by Universitas Indonesia grant (Hibah UI) RAK. The content is solely the responsibility of the authors and does not necessarily represent the official views of the University of Indonesia. None of the funding sources played any role in the design of the study and collection, analysis, and interpretation of data, or in writing the manuscript.

\section{ETHICAL APPROVAL AND INFORMED CONSENT}

Ethical approval and informed consent were not required as aggregate data without individual identifiers were used from existing surveys.

\section{DATA AVAILABILITY}

The data supporting this research are available from the authors on reasonable request.

\section{AUTHORS' CONTRIBUTIONS}

RAK and AA developed the idea for this research. NHW and ARJ conducted data collection and data analysis. RAK, AA, NHW, ARJ and DK drafted the manuscript. DK conducted final editing prior to submission. All authors approved the final version of the manuscript.

\section{PROVENANCE AND PEER REVIEW}

Not commissioned; externally peer reviewed. 